\title{
Naiset ja tekoäly
}

Puhuessani aiheesta "Naiset ja tekoäly" tuhlaan tavallisesti suuren määrän aikaa ja sanoja yrittäessäni vakuuttaa kuulijoille, että otsikkoni osat liittyvät toisiinsa.

Yleisöni koostuu tavallisesti tietokonealan ammattimiehistä, jotka ovat saaneet luonnontieteellisen tai insinöörikoulutuksen. Monet heistä uskovat, että naisten suhde tietokoneisiin on vailla yleistä mielenkiintoa ja olennaista merkitystä. Aihe saattaa kiinnostaa vain feministiä, joka pakkomielteisesti katsoo kaikkia asioita naisnäkökulmasta käsin.

Teknisesti suuntautunut yleisö on tietenkin oikeassa. Naisen ja tekoälyn välillä ei ole olennaista yhteyttä. Olennaista on yhteyden puuttuminen.

Naiset eivät osallistu tietokoneiden suunnitteluun, kehittämiseen eivätkä niiden tutkimiseen. Yhdysvalloissa naisten osuus yliopistotasoisista tietokonealan opiskelijoista on vuosien 1978 ja 1985 välillä laskenut 25 prosentista 11 prosenttiin. Kehityksen suunta ei viimeisen kolmen vuoden aikana ole muuttunut. Wendy Hall ja Gillian Lovegrove ennustavat artikkelissaan Women and AI \& Society -lehden vuoden 1988 syyskuisessa numerossa:

"Lähes kaikki tietoteollisuuden johtajat ja päättäjät tulevat olemaan miehiä. Naiset saattavat päätyä tietotekniikan ammatteihin, mutta on epätodennäköistä, että he saavuttavat korkean aseman kilpaillessaan muodollisen koulutuksen saaneiden miesten kanssa. ... Tämä pitää paikkansa myös päätöksenteon kaikkein korkeimmalla tasolla, hallituksessa ja neuvoa antavissa elimissä."

Kuitenkin valtaosa naisista käyttää tietoteollisuuden tuottamia uusia välineitä päivittäin sekä työssään että vapaa-aikanaan. Uusi tekniikka vaikuttaa heidän työnsä kysyntään, sisältöön ja sen valvontaan. Hallin ja Lovegroven mukaan naisten mahdollisuus vaikuttaa tekniikan kehitykseen ja käyttöönottoon pienenee tulevaisuudessa entisestään.

Miespuolisille tietoteknikoille ja tietämysinsinööreille pitämäni luennot eivät kuitenkaan koske tällaisia satunnaisia tosiasioita, vaan paljon perustavampaa yhteyttä tai eroa, joka vallitsee naisten ja tekoälyn välillä. Väitän, että naiset ja koneet liittyvät toisiinsa tavalla, joka ei ole mielenkiintoinen vain naisliikkeen ja naistutkimuksen näkökulmasta, vaan ratkaiseva myös tietokonetutkimuksen vaativimpien yritysten, tekoälyn ja kognitiotieteen kannalta.

Tekoäly on tietojenkäsittelyopin uusimpia haaroja. Sen tavoitteet määritellään yleensä ihmisen kykyjen avulla seuraavaan tapaan: tekoäly pyrkii rakentamaan ja tutkimaan sellaisista tehtävistä suoriutuvia tietokonejärjestelmiä, jotka edellyttävät ihmiseltä älyä ja tietoa. Määritelmä on käyttökelpoinen, sillä se ei nosta esille hedelmättömiä kysymyksiä älykkyyden olemuksesta ja luonteesta. Tutkijan ei tarvitse pohtia, onko kone todella älykäs vai käyttäytyykö se vain ikään kuin se olisi älykäs. Riittää, että kone kykenee samoihin ulkoisesti havaittaviin suorituksiin kuin ihminen.

Näin määriteltynä tekoälytutkimuksen ei tarvitse ottaa kantaa perinteisiin 
mielenfilosofian ja tieto-opin ongelmiin. Teknologiseen intressiin liittyy kuitenkin toisinaan psykologinen ja filosofinen halu. Jotkut tekoälyn alueella toimivat tutkijat pyrkivät vastaamaan kysymyksiin inhimillisen ajattelun ja tiedon luonteesta sekä mielen suhteesta ruumiiseen.

Kunnianhimoisimmat tekoälytutkijat pitävät ihmiseen kohdistuvaa tutkimusta ensisijaisena tehtävänään ja uskovat löytäneensä vastauksia kysymyksiin, joita Platon ja Aristoteles pohtivat tuloksetta. Uuden tutkimusalan historioitsija Howard Gardner antaa yritykselle tuhatvuotisen perspektiivin:

"Tänään, aseistettuina välineillä ja käsitteillä, jotka eivät olleet kuviteltavissa sata vuotta sitten, uusi ... joukko ajattelijoita on tutkinut monia niistä kysymyksistä, jotka kreikkalaiset nostivat esille noin kaksi ja puoli tuhatta vuotta sitten." (Gardner, Howard: The Mind's New Science: A History of Cognitive Revolution. Basic Books 1985, 5.)

Ihmiseen kohdistuvassa tekoälytutkimuksessa erotetaan yleensä kaksi erivahvuista kantaa. Niin sanotun heikon tekoälyn edustaja uskoo tietokoneohjelmien ja -ohjelmistojen tarjoavan ihmisälyn tutkijoille apuvälineitä, jotka tekevät mahdolliseksi muun muassa hypoteesien täsmällisen muotoilun ja niiden testaamisen.

Vahvan tekoälyn mukaan ihmismieli tai tajunta on kehittynyt tietokoneohjelmisto. Tietokone ei tämän kannan mukaan vain mallina ihmismielen tiloja ja tapahtumia: ajatuksia, mielikuvia, havaintoja ja muistoja. Se käy läpi nämä mentaaliset tilat ja tapahtumat.

Tekoälytutkimuksen psykologiset ja filosofiset tavoitteet saattavat sen osaksi kognitiotiedettä. Nimensä mukaisesti kognitiotiede pyrkii selvittämään, mitä on kognitio: tajunta, havainto, tieto, ymmärrys ja äly. Se ei rajoitu käyttämään vain tekoälyn tietoteknisiä keinoja. Kognitiotieteen rakentajat käyttävät ennakkoluulottomasti hyväkseen myös perinteisen psykologian empiirisiä menetelmiä sekä filosofian spekulatiivista ja käsiteanalyyttistä lähestymistapaa. Tutkimus on olennaisesti poikkitieteellistä.

Kognitiotieteilijät pyrkivät rakentamaan älykkyyden teoriaa, jonka avulla voitaisiin selittää keinotekoisten ja luonnon älykkäitten olioiden käyttäytyminen. Älykkäitten luokkaan lasketaan ihmisten lisäksi joukko eläimiä, mahdolliset ulkoavaruuden rationaaliset olennot sekä pitkälle kehittyneet tietokoneet. Psykologi G. A. Miller kutsuu näitä olioita "informaation ahmijoiksi" (informavores). Zenon Pylyshyn, toinen kuuluisa ja vaikutusvaltainen kognitiotieteilijä, nimittää niitä tietäviksi olioiksi (knowing things) ja tietäjiksi (cogniziers).

Vahvan tekoälyn ja kognitiotieteen perustava oletus on, että rationaalisuus on luonnollinen ominaisuus, jonka tutkija löytää olioista. Olion älykkyys ei riipu sitä tarkkailevan ja kuvailevan tutkijan uskomuksista eikä hänen haluistaan. Se 
ei riipu myöskään yhteiskunnallisesta ja historiallisesta tilanteesta, jossa tutkija ja tutkittava toimivat.

Naistutkimus asettaa tekoälyn ja kognitiotieteen perustan kyseenalaiseksi tuodessaan esille rationaalisuuden käsitteen historiallisuuden sekä sen poliittiset ja normatiiviset ulottuvuudet. Naistutkijoiden rationaalisuus ei löydy oliosta. Se suodaan sille, tai sitä ei suoda. Genevieve Lloyd kirjoittaa teoksessaan The Man of Reason: 'Male' and 'Female' in Western Philosophy (Methuen 1984, X):

"Ne esteet, jotka Ajattelukykyään harjoittava nainen kohtaa, johtuvat suuressa määrin siitä tosiasiasta, että Järjen ideaaleihimme on historiallisesti sisältynyt feminiinisyyden poissulkeminen, ja että feminiinisyys on osittain rakentunut tämän poissulkemisprosessin kautta."

Lloyd osoittaa, miten järki on Platonista ja Aristoteleesta lähtien määritelty luonnon ja ruumiin ylittämiseksi. Augustinus, Tuomas Akvinolainen, Descartes, Hume, Rousseau, Kant, Hegel ovat kaikki nähneet luonnon ja järjen suhteen eri tavoin, mutta kukaan heistä ei murtanut niiden välistä vastakkainasettelua.

Kognitiotiede ja vahva tekoäly muodostavat viimeisen luvun tässä luonnosta ja ruumiista irtaantumisen opissa. Ne lupaavat, että äly voidaan erottaa ihmisruumiista, viime kädessä myös päästä. Eikä kyse ole filosofisesta unelmasta, vaan teknologisesta käytännöstä, vakuuttavat älyn insinöörit. Aivojen wetware on tehokas, muttei välttämätön materiaalinen perusta älykkyydelle. Se voidaan korvata tietokoneen hardwarella.

Feminiininen on tässä ajatusperinteessä yhdistetty siihen, minkä järki ja "rationaalinen tieto ylittävät, mitä ne hallitsevat tai minkä ne yksinkertaisesti jättävät taakseen" (Lloyd 1985, 2). Naisen verta vuotava, maitoa valuva, synnyttävä ja kuoleva ruumis on liittänyt hänet osaksi mielivaltaista ja satunnaista luontoa.

Naistutkijoita eivät kiinnosta käsitteiden väliset yhteydet sinänsä. Mielenkiintoista on se, millaisiin tarkoituksiin näitä yhteyksiä on käytetty: minkä puolesta ja mitä vastaan niiden varassa on argumentoitu.

Naisten oikeuksia ja vapauksia on vielä tällä vuosisadalla pyritty rajoittamaan vetoamalla naisten luontaiseen irrationaalisuuteen. Feminististen vaatimusten vastustajat ovat yrittäneet näyttää, ettei naisen toiminta perustu järkeen, vaan subjektiiviseen ja luonnolliseen tunteeseen. Itävaltalainen filosofi Otto Weininger kirjoitti vuosisadan alussa äidinrakkaudesta:

"Äidinrakkaus on vaistonvarainen ja luonnollinen tunne, ja eläimet kykenevät siihen aivan yhtä suuressa määrin kuin ihmiset. Tämä yksinään riittää osoittamaan, ettei se ole todellista rakkautta, ettei sillä ole moraalista alkuperää; sillä kaikki moraali kumpuaa älyllisestä luonteesta, jota tahtoa vailla 
olevilla eläimillä ei ole. Vain rationaalinen olento voi ymmärtää eettisen imperatiivin." (Weininger, Otto: Sex and Character. Heinemann 1906, 225226.)

Vuosisadan alun feministiset tekstit pyrkivät puolestaan todistamaan, että nainen kykenee samaan kuin mieskin, hän on matemaattinen, looginen ja objektiivinen. Myöhemmin, 1970-luvulta lähtien feministit ovat vaatineet, että rationaalisuuden käsitettä on laajennettava siten, että myös perinteisesti naisellisina pidetyt ominaisuudet ja toiminnat tulevat sen piiriin.

Nainen ei ole ainoa olio, jolta on kiistetty oikeuksia vetoamalla järjen puutteeseen. Samalla perusteella oikeuksia on evätty myös sikiöiltä, eläimiltä, lapsilta, aivovammaisilta ja mielisairailta. Päättely ei etene suoraan järjen puutteesta oikeuksien menettämiseen. Välittävänä tekijänä toimii persoonan käsite.

Vain rationaalinen ja itsestään tietoinen subjekti on persoona ja vain persoonalla on moraalisia ja yhteiskunnallisia oikeuksia. Jos olio luokitellaan järjettömien ja tietoisuutta vailla olevien joukkoon, siitä tulee ei-persoona ja se jää vaille moraalis-yhteiskunnallista asemaa. Järjettömyyden asteesta riippuen olioilta on kielletty erilaisia oikeuksia: oikeus osallistua itseään ja yhteisöä koskeviin päätöksiin, oikeus vapauteen, oikeus terveydeen ja oikeus elämään.

Taustalta löytyy jo Kantin filosofiassa kiteytynyt käsitys, jonka mukaan vain se, joka järkensä avulla kykenee ymmärtämään moraalilain yleiset periaatteet, kuuluu näiden periaatteiden piiriin. Jos olio ei järjen puutteen tai vajavaisen toiminnan takia kykene tajuamaan oikeuttaan, ei oikeus kuulu sille. Toisaalta se ei myöskään ole vastuussa teoista, joita se ei kykene ymmärtämään.

Olennaista ja mielenkiintoista on, että rationaalisuuden ja tietoisuuden käsitteet, jotka toimivat avaimina persoonien valtakuntaan, ovat avoimia. Tämä näkyy naiskeskustelun ohella siinä tavassa, jolla älykkyys pakenee moderneja rakentajiaan. Sitä mukaan kun tekoälytutkijat ovat onnistuneet antamaan koneille älykkyyttä ilmentäviä ominaisuuksia, he itse ovat lakanneet pitämästä näitä ominaisuuksia älykkyyden olennaisina tekijöinä. Näin esimerkiksi looginen päättely ja kielikyky ovat menettäneet hallitsevan aseman älyn tekijöinä. Tilalle on nostettu muun muassa kyky oppia.

Roger Schank kirjoittaa:

"Tekoälytutkijat puhuvat mielellään älykkäistä koneista, mutta ovat vain harvoin yhtä mieltä älykkyyden sisällöstä. ... On selvää, että tekoälyltä puuttuu sen alan rajaava määritelmä." (Schank, Roger: What is AI, Anyway. AI Magazine. Winter 1987, 60.)

Vaikka monet tekoälytutkijat Schankin tapaan myöntävät älyn käsitteen ongelmallisuuden, he eivät yleensä näe ongelman luonnetta. Määritelmän puuttuminen ei johdu tutkimustradition lyhyydestä, ei tutkijoiden ajattelemattomuudesta eikä heidän älyllisestä laiskuudestaan. Avoimuus on osa älyn käsitteen logiikkaa. 
Olio ei ole älykäs siksi, että se toteuttaa jotkut nyt tunnetut tai tulevaisuudessa löydettävät välttämättömät ja riittävät ehdot. Se on älykäs, jos se on riittävän samankaltainen niiden olioiden kanssa, joita pidämme älykkäinä: delfiinien, apinoiden ja tiedemiesten. Riittävästä samankaltaisuudesta päätämme me yhteisönä.

Ludwig Wittgenstein kutsui tällaisia käsitteitä perheyhtäläisiksi. Perheyhtäläisen käsitteen alaan kuuluvilla olioilla ei ole yhteistä olemusta. Älykkäitä olioita ei liitä toisiinsa sen paremmin symbolimanipulaatio kuin heuristinen haku. Sen sijaan ne liittyvät toisiinsa monin erilaisin tavoin. Wittgenstein vertaa sidosta lankaan, jonka vahvuus ei ole siinä, että "jokin säie kulkee langassa koko pituudeltaan, vaan siinä, että monet säikeet ovat langassa päällekkäin". (Wittgenstein, Ludvig: Filosofisia tutkimuksia. WSOY 1981, 93.)

Älyn tutkijoiden langassa kulkee nykyään kielikyky, päättelykyky, kyky asettaa tavoitteita, kyky havaita ulkomaailman olioita ja käsitellä niitä, kyky sopeutua uusiin tilanteisiin, kyky ymmärtää asioiden välisiä suhteita ja merkityksiä. Mutta jos puhuvaa ja päättelevää oliota, esimerkiksi naista tai konetta, ei haluta päästää älypäitten joukkoon, voidaan samanlaisuus peittää erojen moninaisuudella. 